\title{
The Influence of Thinning Agent on Base of 6-BA and NAA on Productivity and Fruit Quality of "Gala Must” Variety
}

\author{
Ananie PESTEANU ${ }^{1 *}$ \\ 1) Faculty of Horticulture. State Agrarian University of Moldova, Republic of Moldova. \\ ${ }^{*}$ Corresponding author, e-mail: a.pesteanu@uasm.md
}

BulletinUASVM Horticulture 72(1) / 2015

Print ISSN 1843-5254, Electronic ISSN 1843-5394

DOI:10.15835/buasvmcn-hort:10496

\begin{abstract}
Chemical thinning of pome fruits is important measure for the profitable agricultural production of fruits. Chemical thinning provides a good yield potential for the following vegetation. Thinning the apple crop during the post bloom period is absolutely essential to ensure large fruit size, superior fruit quality, and reliable annual cropping. To evaluate the influence of thinning agent on base of 6-benzyladenine (6-BA) and naphthalene acetic acid (NAA) in reducing fruit set and quality in Gala Must apple trees. The experimental plot was founded in 2006 with trees of „knip boom” canopy type. The study subject of the experience was Gala Must apple variety grafted on M 9. The trees were trained as slender spindles. The distance of plantation is $3.5 \times 1.2 \mathrm{~m}$. The tested combination was 6-BA and NAA. The preparation was sprayed on the trees either one time, when the king fruit diameter was 10-15 mm. The research was conducted during the period of 2011 year. During the research, it was studied the number of blossom clusters before thinning degree, fruit at harvest time, yield, mean fruit weight, average fruit diameter, size classes based on their diameter and the number of pygmy fruits. It was established that, the good effect of thinning was noticed after single application of $100 \mathrm{ppm} 6-\mathrm{BA}+\mathrm{NAA} 10 \mathrm{ppm}$. The combined treatment with 6-BA $100 \mathrm{ppm}+$ NAA $10 \mathrm{ppm}$ has a significant effect on yield, mean fruit weight and positively influenced fruit size, the distribution of apples in size classes.
\end{abstract}

Keywords: apple, 6-BA and NAA, size classes, thinning, yield.

\section{INTRODUCTION}

In recent years 'Gala Must' is one of the most important cultivars grown in Repablic of Moldova. It is also one of the most widely accepted apples on the world market. Gala-derived cultivars typically produce more flowers and fruit than are needed to produce a full crop of marketable fruit (Basak, 2006; Bregoli et al.; 2007; Costa et al., 2001; Stopar, 2002).

Hand thinning of the apple trees can be very accurate, but it is extremely expensive, and requires skilled labour inputs ( Costa et al., 2001). Heavy crop loads inhibit the ability of the tree to develop blossom buds for the following year, resulting in biennial bearing (Greene, 2002; Pesteanu, 2013; Tromp, 2000; Wertheim, 2000).
Gala cultivars have the high fertility and the extended bloom period. Therefore, this cultivars should be first thinned chemically, and only then by hand if needed (Basak, 2006; Costa et al., 2001).

Chemical thinning with bioregulators decreases fruit set, increases average fruit weight of different apple cultivars and provides a good yield potential for the following vegetation (Basak, 2004; Greene, 2002; Petracek and Silverman, 2003; Robinson, 2006; Stern et al., 2006; Stopar, 2000).

Chemical fruit thinning methods were tested by different researchers in many countries. Generally, plant growth regulators are used such as NAA, NAD, BA and ethephon for fruit thinning. Some of the fruit thinners can reduce fruit quality. 
In addition, their effects may change depend on weather temperature in application time (Basak, 2004; Greene, et al., 1990; Robinson et al., 1998; Robinson and Lakso, 2000; Wertheim, 1997).

1-naphthaleneacetic acid (NAA) is an old thinning compound which is based on its hormonal action as a synthetic auxin (Sebek, 2014; Stopar, 2002). The mechanism of action of NAA is based on the stimulation of ethylene synthesis taking place in fruitlet tissue. It has also been ascertained that the natural drop of fruitlets is always connected with an increase in ethylene synthesis and evolution (Dennis, 2000). The effectiveness of fruitlet thinning with NAA is often unsatisfactory. The efficacy of the treatment depends on the weather which affects the intensity of the agent penetrating into leaf tissue (Basak, 2004). This can influence the intensity of ethylene synthesis and evolution and ultimately determine the effectiveness of the treatment. The most effective time to apply NAA as a chemical thinner is when fruit diameter is 7 to $9 \mathrm{~mm}$ or 11 to $13 \mathrm{~mm}$ (Greene, 2002; Pesteanu, 2013;).

Synthetic cytokinin 6-benzyladenine (BA) has been found to be a good thinning agent. BA thins fruitlets best at $10 \mathrm{~mm}$ fruitlet diameter and has a positive influence on return bloom (Robinson et al., 1998; Greene, 1993). The advantage of BA as a synthetic cytokinin is its influence on hastened cell division so that the fruit enlargement should be greater than we could expect from its thinning action (Greene, 1993; Stopar and Zadravec, 2001).

The combination spraying of BA and NAA is sometimes recommended to get a stronger thinning response or to use lower rates of each thinner (Robinson et al., 1998; Sebek, 2014). The aim of this study was to examine the efficacy of BA and NAA combination for the Gala Must cultivar in climatic condition of Republic Moldova.

\section{MATERIALS AND METHODS}

The research was conducted during the period of 2011 year in the superintensive apple tree orchard, growing at a village Sirota form district Orhei in the autumn of 2006 year at the Ltd. „Dacfruct” with trees of a „knip boom” canopy type.

The study subject of the experience was Gala Must apple variety grafted on M 9 weak vigour rootstock. The trees were trained as slender spindles. The distance of plantation is $3.5 \times 1.2 \mathrm{~m}$.
To optimize the fruit load of the apple trees were experimented the following variants of treatment:

1. Control - no treatment;

2. BA $100 \mathrm{ppm}+\mathrm{NAA} 10 \mathrm{ppm}$;

3. BA $140 \mathrm{ppm}+\mathrm{NAA} 14 \mathrm{ppm}$.

The treatments were carried out when the central fruit on the tree reached a value of fruit diameter ranging from $10 \mathrm{~mm}$ to $15 \mathrm{~mm}$.

The soil was maintained with grass on intervals between rows and herbicided field between trees on row with a width of 1,2 m. It was used the drip irrigation system.

The plots placement was made in blocks, each variant having three repetitionsand each one repetition consisted of 7 trees. At the boundaries between the plots and the experimental repetitions was left per 1 untreated tree to avoid duplication of some control variants or repetitions on making the treatments.

On experimental section in accordance with the experiences scheme, in the second variant was performed only one spray (5/23/11) with BA 100 ppm + NAA $10 \mathrm{ppm}$ when the central fruit size diameter is $10-15 \mathrm{~mm}$. In the third variant was also performed a single treatment with BA 140 ppm + NAA 14 ppm $(5 / 23 / 11)$ when the central fruit size diameter is $10-15 \mathrm{~mm}$. The treatment was performed by a portable watering tool during the hours without wind in the morning, at a temperature of $+180 \mathrm{o}$, with tendency of temperature growth.

The amount of solution to a tree was 0.4 to 0.5 liters, based on the number of trees per unit area and the amount of water recommended by the 1000 l/ha. For a more positive grip of the solution with a leaf surface was added Silwet L77 from the ratio of $1 \mathrm{ml}$ to 10 liters of water.

The effects on the fruit set, the yield, fruit quality at harvest and subsequent blooming were recorded and evaluated according to the following measurements: the number of inflorescences and the number of fruitlets on each tree; the fruit yield produced by each tree, and, for 1 ha orchard of apples; weight of 1 apple; the share of fruits (in $\%$ ) in size classes based on their diameter from $50 \mathrm{~mm}$ to $80 \mathrm{~mm}$ with the intervals of $5 \mathrm{~mm}$ and relative effectiveness of treatments.

Thus, we see that the weather conditions during the surveys differ as between them and to 
the multiannual average, but it were typical for the area and conducive to grow apple fructification and BA + NAA treatment.

\section{RESULTS AND DISCUSSIONS}

Investigations made demonstrate that in the period of 2010 year the Gala Must apple trees had differentiated a sufficient amount of bud fruit, that after pruning during the resting period in the summer of 2011 have formed 160168 inflorescences (Tab. 1). The given amount of inflorescences demonstrates that the fruit trees have an uniform development and there are no big differences between them. It is maintained a co-report between the growth and fructification and because of the plot uniformity can be made experiences to test the combination of thinning agent $\mathrm{BA}+\mathrm{NAA}$ according to the present program.

The investigations made show that the thinning agent on base of BA + NAA in the period when central fruit dimension was $10-15 \mathrm{~cm}$ in diameter had an influence on physiological fruit fall. In the control variant without thinning, the number of inflorescences was about $104 \mathrm{pcs} /$ tree, or $63.8 \%$ of their total number. In variants 2 and 3 , where is tested the thinning agent BA + NAA, the number of flowers was about 51-56 piece/tree, diminished from 1.86 to 2.04 times compared with control variant.

Studying the number of inflorescences formed at the variants with BA + NAA treatment, it is registered that the largest weight of flowers formed is in case is used the combination of BA 100 $\mathrm{ppm}+\mathrm{NAA} 10 \mathrm{ppm}-56 \mathrm{pcs} /$ tree. If to increase the dose to BA $140 \mathrm{ppm}+\mathrm{NAA} 14 \mathrm{ppm}$, then the total number of inflorescences was about $51 \mathrm{pcs} /$ tree.

It is known that production quality is higher when in a single inflorescence is developing in the growing fruit. The investigations show that the most rational location of fruit was in the variant where it was tested the combination of BA 100 ppm + NAA $10 \mathrm{ppm}$. In this case $83.9 \%$ from fruits are situated by one in an inflorescence, $12.5 \%$ - by two, and 3.6 - by three. When increasing the dose to BA $140 \mathrm{ppm}+\mathrm{NAA} 14 \mathrm{ppm}$, it increases also the weight of fruits from 2 to 3 pieces in inflorescence diminishing to that with a single one.

In control variant $55.7 \%$ of the fruit number are placed by one in inflorescence, $34.6 \%$ - by two, $8.6 \%$ - by three and $1.1 \%$ - four.

Therefore, it was established that the combined aplication of BA + NAA influenced on the number of inflorescences formed in the tree crown. Simultaneously the weight of single fruits increased from 16.8 to $28.2 \%$, registering more favorable values where it was tested the combination of BA 100 ppm + NAA 10 ppm.

Fruit production is a final index that is in a close connection to all the agro-technical procedures that are done in the orchard and are greatly different in comparison with the recommended dose of the growth regulator.

Apple tree treatments with $\mathrm{BA}+\mathrm{NAA}$ combination had an influence on the number of fruits per tree according to the variant taken into the study (Tab. 2). The greatest quantity of fruits is registered at the control variant where it was made no treatment - $161 \mathrm{pcs} /$ tree. Then in a descendant order is situated the variant BA $100 \mathrm{ppm}+\mathrm{NAA}$ $10 \mathrm{ppm}-69 \mathrm{pcs} /$ tree and the variant BA $140 \mathrm{ppm}$ + NAA 14 ppm - 68 pcs/tree, from which 8 are of "pygma” type. This demonstrates that the higher quantity of BA does not permit the split of cells in the fruit and their weight increase.

The study on fruit number per 100 inflorescences demonstrates an identical rule with the previously described one, constituting, corespundingly, 98, 41 and 38 pcs/100 inflorescences.

Tab. 1 Total inflorescences number (TIN), formed (FIN) in Gala Must apple tree variety canopy and the fruit weight in an inflorescence

\begin{tabular}{ccccccc}
\hline $\begin{array}{c}\text { Variants of } \\
\text { treatment }\end{array}$ & $\begin{array}{c}\text { TIN, } \\
\text { pcs/tree }\end{array}$ & $\begin{array}{c}\text { FIN, } \\
\text { pcs/tree }\end{array}$ & \multicolumn{4}{c}{ Fruit weight in an inflorescence, \% } \\
\hline Control & 163 & 104 & 55.7 & 34.6 & 8.6 & 1.1 \\
\hline $\begin{array}{c}\text { BA 100 ppm + NAA } \\
10 \text { ppm }\end{array}$ & 168 & 56 & 83.9 & 12.5 & 3.6 & - \\
\hline $\begin{array}{c}\text { BA 140 ppm + NAA } \\
14 \text { ppm }\end{array}$ & 160 & 51 & 72.5 & 23.5 & 4.0 & - \\
\hline
\end{tabular}


Tab. 2 Influence of BA + NAA combination on Gala Must apple tree production and quality parameters on harvest

\begin{tabular}{cccccccc}
\hline \multirow{2}{*}{ Variants of treatment } & \multicolumn{2}{c}{ Fruit number, pcs } & \multicolumn{3}{c}{ Fruit production } & \multirow{2}{*}{$\begin{array}{c}\text { Average } \\
\text { weight, g }\end{array}$} & $\begin{array}{c}\text { Average } \\
\text { diameter,mm }\end{array}$ \\
\cline { 2 - 6 } tree & $\begin{array}{c}100 \\
\text { inflores. }\end{array}$ & $\begin{array}{c}\mathrm{kg} / \mathrm{cm}^{2} \\
\text { TTS }\end{array}$ & $\begin{array}{c}\mathrm{kg} / \\
\text { tree }\end{array}$ & $\mathrm{t} / \mathrm{ha}$ & 79.5 & 56.0 \\
\hline $\begin{array}{c}\text { BA 100 ppm + NAA } \\
10 \mathrm{ppm}\end{array}$ & 69 & 41 & 1.02 & 9.58 & 22.80 & 138.8 & 68.0 \\
\hline $\begin{array}{c}\text { BA 140 ppm + NAA } \\
14 \mathrm{ppm}\end{array}$ & $60 / 8^{*}$ & 38 & 0.64 & 7.21 & 17.16 & 120.1 & 62.2 \\
\hline LSD 5\% & 7.52 & - & - & 0.68 & 1.62 & 0.96 & - \\
\hline
\end{tabular}

* -number of small fruit called „pygma”

Because, the smallest number of fruit per a tree and for 100 inflorescences was registered in the control variant a higher production per plant and surface unit was obtained in the same variant constituting, respectively, $12.80 \mathrm{~kg} /$ tree and 30.46 $\mathrm{t} / \mathrm{ha}$. A yield diminishment was registered in the variant BA $100 \mathrm{ppm}+\mathrm{NAA} 10 \mathrm{ppm}$, where the fruit production constituted $9.58 \mathrm{~kg} /$ tree and $22.80 \mathrm{t} /$ ha. In case of applying the treatment with BA 140 ppm + NAA 14 ppm, it is registered an essential dicrease of fruit production to $7.21 \mathrm{~kg} /$ tree, which is statistically demonstrated and decrease with $13.30 \mathrm{t} / \mathrm{ha}$ in comparisson with the control variant.

Statistic processing data demonstrate us that a different statistic exists in all cases between the variants taken into the study.

Trunk transversal surface (TTS) is an index that permanently plantation productivity settlement. The investigations made demonstrates that the highest fruit productivity per $1 \mathrm{~cm}^{2}$ TTS was registered in the control variant -1.20 $\mathrm{kg}$, where the fruit tres were not exposed to the process of thinning. There were obtained the highest values in the variant BA $100 \mathrm{ppm}+$ NAA 10 ppm, where the fruit production constituted 1.02 $\mathrm{kg} / \mathrm{cm}^{2} \mathrm{TTS}$, or was registered a decrease of $15.0 \%$ in comparisson with the variant control. With the decrease the dose to BA 140 ppm + NAA 14 ppm, fruit production diminishes with $87.5 \%$ in comparisson with the control variant constituting $0.64 \mathrm{~kg} / \mathrm{cm} 2$ TTS.

Fruit quality it means a fruit average weight and diameter. Investigations made demonstrate that combination of BA + NAA as a preparation for fruit chemical thinning had a great influence on production quality. If in the control variant, were there was made no chemical thinning, the average weight per a Gala Must apple fruit constituted 79.5 $\mathrm{g}$, then the variants where is tested combination of BA + NAA, increased to 120.1-138.8 g. Studying the influence of thinning agent of fruit average weight registering higher values then the case when it made used treatment with BA $100 \mathrm{ppm}$ + NAA 10 ppm - 138.8 g. With increase dose of thinning agent (BA $140 \mathrm{ppm}+$ NAA $14 \mathrm{ppm}$ ) the average weight per a fruit dimishes with $18.7 \mathrm{~g}$ in comparisson with the previous variant.

Fruit average diameter is an indicator with a direct tangency on average weight of obtained production. The lowest average diameter was registered in the control variant $-56.0 \mathrm{~mm}$, where the trees were no thinning. Thus, in growth was places the variant BA $140 \mathrm{ppm}+\mathrm{NAA} 14 \mathrm{ppm}-$ $62.2 \mathrm{~mm}$ and variant BA $100 \mathrm{ppm}+\mathrm{NAA} 10 \mathrm{ppm}$ $-68.0 \mathrm{~mm}$.

The obtained results demonstrates that the highest fruit production was registered in the control variant, but the production quality is poor. In case of using BA $100 \mathrm{ppm}+$ NAA $10 \mathrm{ppm}$ application it was registered a decrease of of fruit production, but and increase of their quality. Increasing the dose of BA $140 \mathrm{ppm}+$ NAA $14 \mathrm{ppm}$ does not permit fruit development in comparisson with the previous variant. This is explained by the fact of "pigma” fruit type appearence, diminishing the fruit number per a tree, average weight and diameter decreases, finally influencing the fruit production quantity and quality. 
The investigations made demonstrates us that there is a proportional ratio between the fruit weight depending on the diameter and the experiences variant. As the number of fruits in crown is higher than the fruit weight with a small diameter increases and vice versa.

The study was not based only on knowing the average diameter of fruit, but knowing also the repartition of fruit per diameter from 5 to $5 \mathrm{~mm}$ in conformity with the experiences' variants.

Table 3 data demonstrates that in the control variant was produced an inferior net quality production. The highest weight $(39.6 \%)$ is in the class with a lower diameter of $55 \mathrm{~mm}, 46.9 \%$ with a diameter of $56-60 \mathrm{~mm}$ and only $13.5 \%$ have a diameter of 61-65 mm. Thus, extra category and category I fruit in the control variant, without thinning, do not exist.

Continuing to study the influence of growth regulator on fruit quality, we register a more rational redistribution according to the trade standards in the variaant BA $100 \mathrm{ppm}+$ NAA $10 \mathrm{ppm}$. In the given variant the fruit weight with a smaller diameter of 65 mm constituted $22.8 \%$. In category I, the fruit with a diameter of $66-70 \mathrm{~mm}$ constituted $36.1 \%$, but at the extra category is $41.1 \%$ from fruits. Thus, extra category and category I fruit weight constituted $77.2 \%$.
In case when treating with BA $140 \mathrm{ppm}+\mathrm{NAA} 14$ ppm we register an increase of fruit weight in the class with a diameter of $<55-65 \mathrm{~mm}(56.2 \%)$ and a decrease of fruit quantity that is attributed to the diameter 66$75 \mathrm{~mm}(35.2 \%)$. Extra category and category I fruit weight constitutes $43.8 \%$, or a decrease with $33.4 \%$ in comparisson with the variant BA $100 \mathrm{ppm}+$ NAA 10 ppm.

Diameter index $(R)$ constitutes the ratio of yield total quantity and quantity with a diameter less than $70 \mathrm{~mm}$. The investigations made (Tab. 4) demonstrates that in the control variant the total fruit production per tree with a diameter lower than $70 \mathrm{~mm}$ is identical. As a result, diameter index, production and global indices is equal with 1.0.

When the amount of fruits withg the diametrer lower than $70 \mathrm{~mm}$ dicreases, the diametrer index increase in fields treates with BA $100 \mathrm{ppm}+\mathrm{NAA}$ $10 \mathrm{ppm}$ is 1.69 and when we using BA $140 \mathrm{ppm}+$ NAA 14 ppm we notice higher values than in control variant, but with $25.2 \%$ lower than in variant 2 .

To have higher production values index it is necessary that fruit production in the variants with treatments to be bigger than in the control variant. Investigations made demonstrate that a lower production index actions in case of treating with BA $140 \mathrm{ppm}+\mathrm{NAA} 14 \mathrm{ppm}-0.56$, then, in

Tab. 3 Influence of BA + NAA combination on redistribution of fruit according to their diameter at Gala Must apple tree variety

\begin{tabular}{ccccccc}
\hline \multirow{2}{*}{ Variants of treatment } & \multicolumn{5}{c}{ Fruit weight (\%) in accordance to their diameter (mm) } \\
\cline { 2 - 7 } & 39.6 & $56-60$ & $61-65$ & $66-70$ & $71-75$ & $76-80$ \\
\hline Control & 46.9 & 13.5 & - & - & - \\
\hline $\begin{array}{c}\text { BA 100 ppm + NAA 10 } \\
\text { ppm }\end{array}$ & - & 5.0 & 17.8 & 36.1 & 32.2 & 8.9 \\
\hline $\begin{array}{c}\text { BA 140 ppm + NAA 14 } \\
\text { ppm }\end{array}$ & 9.5 & 17.6 & 29.1 & 17.9 & 17.3 & 8.6 \\
\hline
\end{tabular}

Tab. 4 Treatment relative efficiency for chemical thinning with BA + NAA combination in Gala Must variety plantation

\begin{tabular}{|c|c|c|c|c|c|}
\hline \multirow[b]{2}{*}{ Variants of treatment } & \multicolumn{2}{|c|}{ Fruit production, kg/tree } & \multicolumn{3}{|c|}{ Index } \\
\hline & total & $\mathrm{cu} \varnothing<70 \mathrm{~mm}$ & diameter (R) & $\begin{array}{l}\text { production } \\
\text { (P) }\end{array}$ & global (G) \\
\hline Control & 12.80 & 12.80 & 1.0 & 1.0 & 1.0 \\
\hline $\begin{array}{c}\text { BA } 100 \mathrm{ppm}+\mathrm{NAA} \\
10 \mathrm{ppm} \\
\end{array}$ & 9.58 & 5.65 & 1.69 & 0.75 & 1.27 \\
\hline $\begin{array}{c}\text { BA } 140 \mathrm{ppm}+\mathrm{NAA} \\
14 \mathrm{ppm} \\
\end{array}$ & 7.21 & 5.35 & 1.35 & 0.56 & 0.76 \\
\hline
\end{tabular}


an ascendant order, is placed the variant BA 100 ppm + NAA 10 ppm - 0.75, and the control variant, without thinning -1.0 .

The global index $(G)$ constitutes the product of prduction diameter index and production index. The lowest values of global index are registered in the variant BA $140 \mathrm{ppm}+\mathrm{NAA} 14 \mathrm{ppm}-0.76$ and control variant (1.0). In the variant of treating with BA $100 \mathrm{ppm}+$ NAA $10 \mathrm{ppm}$, we register the highest global index -1.27 .

The researches made demonstrates that the highest values of real efficiency (diameter and global index) are registered in the variant with use combined application where the active substance of the product was BA $100 \mathrm{ppm}+\mathrm{NAA} 10 \mathrm{ppm}$.

\section{CONCLUSION}

It was observed that inadequate thinning influenced on fruit weight in inflorescence, number of fruits on tree, fruit production, average weight and average diamete, fruit redistribution according to their diameter and on the relative effectiveness of treatments.

It was demonstrated that combination of $\mathrm{BA}$ and NAA can be active as a thinner for the 'Gala Must' cultivar, when the sizes of king fruit diameter was from $10 \mathrm{~mm}$ to $15 \mathrm{~mm}$.

Based on obtained experimental results the combined application where the active substance of the product was BA $100 \mathrm{ppm}+$ NAA $10 \mathrm{ppm}$ may be included in the system of chemical thinning to optimize the apple fruit load on 'Gala Must' cultivar.

The treatment with BA $140 \mathrm{ppm}+\mathrm{NAA} 14$ ppm caused a deacrease in average fruit, weight and appearance of fruits of „pygma” type.

\section{REFERENCES}

1. Basak A (2004). Fruit thinning by using benzyladenine (BA) with ethephon, ATS, NAA, urea and carbaryl in some apple cultivars. Acta Horticulturae 653:99-106.

2. Basak A (2006). The effect of fuitlet thinning on fruit quality parametrs in the apple cultivar 'Gala'. Journal of Fruit and Ornamental Plant Research 14(2):143-150.

3. Bregoli AM, Fabbroni C, Vancini R, Galliano A, Costa G (2006). Results obtained on the efficacy of 6-BA alone, and in combination with other thinning agents from different apple producing areas of Northern Italy. Journal of Fruit and Ornamental Plant Research 14:23-38.

4. Costa G, Corelli-Grappadelli L, Bucchi F (2001). Studies on apple fruit abscission and growth as affected by cytokinins. Acta Horticulturae 557:243-249.
5. Dennis FG (2000). The history of fruit thinning. Plant Growth Regulation 31:1-16.

6. Greene DW, Autio WR, Miller P (1990). Thinning activity of benzyladenine on several apple cultivars. J. Amer. soc. hort. sci 115:394-400.

7. Greene DW (1993). A review of the use of benzyladenine (BA) as a chemical thinner for apples. Acta Horticulturae 329:231-236.

8. Greene DW (2002). Chemicals, timing, and environmental factors involved in thinner efficacy on apple. Hortscience 37:477-480.

9. Pesteanu A (2013). Efficiency of fruitlet thinning apple"Golden Reinders" by use naphthylacetamide acid (NAD). Bulletin of University of Agricultural Sciences and Veterinary Medicine Cluj-Napoca 70(1):180-186.

10. Pesteanu A (2013). Fruit thinning by using NAA agent on the Jonagored apple variety. Annals of the University of Craiova 18(LIV):267-272.

11. Petracek PD, Silverman FP (2003). A history of commercial plant growth regulators in apple production. HortScience 38:937-942.

12. Robinson T, Lakso A, Stover E, Hoying S (1998). Practical apple thinning programs for New York. New york fruit quarterly 6:14-18.

13. Robinson TL, Lakso A N (2000). Between year and within year variations in chemical fruit thinning efficacy of apples during cool springs. Acta Horticulturae 636:283-294.

14. Robinson LT ( 2006). Interaction of benzyladenine and naphtaleneacetic acid on fruit set, fruit size and crop value of twelve apple cultivars. Acta Horticulturae 727:283-290.

15. Sebek G (2014). Application of NAA and BA in Chemical Fruit Thinning of Autochthonous Cultivars of Apple. Journal of Agricultural Science and Technology 4:21-28.

16. Stern A R, Ben-Araie R, Applebaum S, Flaishman M (2006). Cytokinins increase fruit size of Delicious and Golden Delicious (Malus domestica) apple in a warm climate. Journal of Horticultural Science and Biotechnology 81(1):51-56.

17. Stopar M (2000). Comparison of the most frequently used apple thinning compounds for the thinning of 'Elstar' and 'Golden delicious' apples. Res. rep. biot. fac. Agriculture 75:89-94

18. Stopar M, Zadravec P (2001). New apple thinning agents and their combination evaluated on cultivar Gala. Sodobno kmetijstvo 34:154-158.

19. Stopar M (2002). Thinning of "Gala" and "Golden Delicious" apples with BA, NAA and their combinations. Journal of Central European Agriculture 3(1):1-6.

20. Tromp J (2000). Flower-bud formation in pome fruits as affected by fruit thinning. Plant Growth Regulation 31(12):27-34.

21. Wertheim SJ (1997). Chemical thinning of deciduous fruit trees. Acta Horticulturae 463:445-455.

22. Wertheim SJ (2000). Developments in the chemical thinning of apple and pear. Plant Growth Regulation 31(1-2):85-100. 